\title{
Research Article \\ p-Coumaric Acid Protects Human Lens Epithelial Cells against Oxidative Stress-Induced Apoptosis by MAPK Signaling
}

\author{
Jiao Peng, ${ }^{1,2,3}$ Ting-ting Zheng, ${ }^{4}$ Yue Liang, ${ }^{1}$ Li-fang Duan, ${ }^{1}$ Yao-dong Zhang, ${ }^{1}$ Li-Jun Wang, \\ Guang-ming He, ${ }^{1}$ and Hai-tao Xiao ${ }^{2}{ }^{2}$ \\ ${ }^{1}$ Department of Pharmacy, Peking University Shenzhen Hospital, Shenzhen 518035, China \\ ${ }^{2}$ School of Pharmaceutical Sciences, Health Science Center, Shenzhen University, Shenzhen 518060, China \\ ${ }^{3}$ The Key Laboratory of Pharmacology and Druggability for Natural Medicines, Department of Education, Guizhou Medical \\ University, Guiyang, Guizhou 550025, China \\ ${ }^{4}$ Shenzhen Key Laboratory for Drug Addiction and Medication Safety, Department of Ultrasound, Shenzhen-PKU-HKUST Medical \\ Center, Peking University Shenzhen Hospital and Biomedical Research Institute, Shenzhen 518036, China
}

Correspondence should be addressed to Hai-tao Xiao; xhaitao@szu.edu.cn

Received 5 January 2018; Accepted 19 February 2018; Published 10 April 2018

Academic Editor: Renata Szymanska

Copyright @ 2018 Jiao Peng et al. This is an open access article distributed under the Creative Commons Attribution License, which permits unrestricted use, distribution, and reproduction in any medium, provided the original work is properly cited.

To protect against oxidative stress-induced apoptosis in lens epithelial cells is a potential strategy in preventing cataract formation. The present study aimed at studying the protective effect and underlying mechanisms of $p$-coumaric acid ( $p$-CA) on hydrogen peroxide- $\left(\mathrm{H}_{2} \mathrm{O}_{2}^{-}\right)$induced apoptosis in human lens epithelial (HLE) cells (SRA 01-04). Cells were pretreated with $p$-CA at a concentration of 3,10 , and $30 \mu \mathrm{M}$ before the treatment of $\mathrm{H}_{2} \mathrm{O}_{2}(275 \mu \mathrm{M})$. Results showed that pretreatment with $p$-CA significantly protected against $\mathrm{H}_{2} \mathrm{O}_{2}$-induced cell death in a dose-dependent manner, as well as downregulating the expressions of both cleaved caspase- 3 and cleaved caspase- 9 in HLE cells. Moreover, p-CA also greatly suppressed $\mathrm{H}_{2} \mathrm{O}_{2}$-induced intracellular ROS production and mitochondrial membrane potential loss and elevated the activities of T-SOD, CAT, and GSHPx of $\mathrm{H}_{2} \mathrm{O}_{2}$-treated cells. As well, in vitro study showed that $p$-CA also suppressed $\mathrm{H}_{2} \mathrm{O}_{2}$-induced phosphorylation of $\mathrm{p}$-38, ERK, and JNK in HLE cells. These findings demonstrate that $p$-CA suppresses $\mathrm{H}_{2} \mathrm{O}_{2}$-induced HLE cell apoptosis through modulating MAPK signaling pathways and suggest that $p$-CA has a potential therapeutic role in the prevention of cataract.

\section{Introduction}

Age-related cataracts are the leading causes of blindness among the elderly population, affecting nearly $50 \%$ of 180 million visually impaired people in the world [1]. Although the surgery has proved effective for cataracts, it still exists in many risks and complications [2]. It is estimated that if the onset of clinical cataract can be delayed for 10 years, half of the cataract surgeries will not be necessary [3]. Thus, to delay or prevent cataract development would be important both for increasing the well-being of older adults and for reducing medical care costs. Oxidative stress caused by reactive oxygen species (ROS) has long been recognized as the major contributor to the formation of cataract, and hydrogen peroxide $\left(\mathrm{H}_{2} \mathrm{O}_{2}\right)$ is the main intracellular ROS in the aqueous humor, which can activate multiple signaling events such as the activation of the caspases, the Bcl-2 family, the mitogenactivated protein kinases (MAPKs), and NF- $\kappa$ B pathways to induce lens epithelial cell (HLE) apoptosis and cause lens opacification, resulting in subsequent cataract development [4-7]. Therefore, to protect human lens epithelial cells from oxidative stress-induced apoptosis is an important strategy in preventing and delaying cataract formation.

$p$-Coumaric acid ( $p$-CA) is a phenolic acid which is widely distributed in many plants and human diets such as cereals, fruits, and vegetables, possessing versatile medicinal activities including antioxidant, cardioprotective, antimelanogenic, antimutagenic, antiplatelet, anti-inflammatory, and immunomodulatory actions [8-13]. Previous studies reported that $p$-CA is effective to protect the cornea from 
UVB-induced oxidation damage in vivo and in vitro [14-16]. Other studies also proposed that $p$-CA could prevent cells from oxidative stress-induced apoptosis [17, 18]. However, the molecular mechanisms behind its protection against oxidative stress remain unknown. In our preliminary work, we screened the protective effects of natural compounds on $\mathrm{H}_{2} \mathrm{O}_{2}$-induced oxidative damage in human lens epithelial cells and found that $p$-CA exerts a potent protective effect on $\mathrm{H}_{2} \mathrm{O}_{2}$-induced oxidative stress in human lens epithelial cells (SRA 01-04). In the present study, we therefore investigated the effect of $p$-CA on $\mathrm{H}_{2} \mathrm{O}_{2}$-induced apoptosis in human lens epithelial (HLE) cells and its molecular mechanisms involved.

\section{Materials and Methods}

2.1. General. Fetal bovine serum (FBS), 0.25\% trypsin, and DMEM/F12 medium were obtained from Gibco (Grand Island, NY, USA). Dimethyl sulfoxide (DMSO), $\mathrm{H}_{2} \mathrm{O}_{2}$, cocktail of protease inhibitors, and 3-(4,5-dimethylthiazol-2-yl)-2,5-diphenyltetrazolium bromide (MTT) were purchased from Sigma Chemical Co. (St. Louis, MO, USA). Quick start Bradford 1x dye reagent was from Bio-Rad Laboratories Inc. (Berkeley, California, USA). Anti-cleaved caspase-3, anti-cleaved caspase-9, anti-p-p38, anti-p-ERK, anti-p-JNK, anti- $\beta$-actin, U0126, LY2228820, and SP600125 were obtained from Cell Signal Technology (Beverly, MA, USA). The ECL detection kit was acquired from Amersham Pharmacia (Arlington Heights, IL, USA). The annexin V/FITC kit was purchased from eBioscience (Bender MedSystems GmbH, Vienna, Austria). T-SOD, CAT, and GSH-Px colorimetric activity assay kits were purchased from Jiancheng Bioengineering Institute (Nanjing, China). H2DCF-DA was obtained from Beyotime (Beyotime Institute of Biotechnology, Shanghai, China).

2.2. Cell Culture. Human lens epithelial (HLE) cells SRA 01/ 04 were purchased from the Chinese Academy of Medical Sciences (Beijing, China). The HLE cells were cultured as a monolayer in DMEM/F12 medium supplemented with 15\% heat-inactivated FBS, penicillin $(100 \mathrm{U} / \mathrm{mL})$, and streptomycin $(100 \mu \mathrm{g} / \mathrm{mL})$ and were maintained under standard cell culture conditions at $37^{\circ} \mathrm{C}$ in a humidified atmosphere of $5 \% \mathrm{CO}_{2}$. The cells were routinely subcultured every 2-3 days.

2.3. Cell Viability. The cells were cultured in 96-well microplates with a density of $1 \times 10^{4}$ cells/well and incubated with different concentrations of $p$-CA $(0-100 \mu \mathrm{M})$, respectively, with or without the exposure of $\mathrm{H}_{2} \mathrm{O}_{2}$. After $24 \mathrm{~h}$ incubation, the culture medium was removed and cell viability was measured using the MTT method as previously described [19].

2.4. Detection of Cell Apoptosis. The percentage of apoptotic cells was assayed using the annexin V/FITC apoptosis detection kit according to the manufacturer's directions. Briefly, cells were plated and incubated in 6-well plates at a density of $1 \times 10^{6}$ cells/well. After exposure to $\mathrm{H}_{2} \mathrm{O}_{2}(275 \mu \mathrm{M})$ and/ or indicated concentrations of $p$-CA for $6 \mathrm{~h}$, the cells were harvested by $0.25 \%$ trypsin and washed twice with ice-cold PBS. The cell pellets were resuspended in binding buffer (1x) prior to the addition of $5 \mu \mathrm{L}$ FITC-labeled annexin $\mathrm{V}$ and $10 \mu \mathrm{L}$ propidium iodide (PI) for $15 \mathrm{~min}$ at room temperature in the dark. The level of cell apoptosis was immediately analyzed on a flow cytometer (Becton Dickinson, San Jose, CA, USA).

2.5. Reactive Oxygen Species (ROS) Generation Assay. The intracellular ROS levels were evaluated using the ROSspecific fluorescent dye H2DCF-DA. After indicating treatments, cells were washed with PBS for three times and stained with $\mathrm{H} 2 \mathrm{DCF}-\mathrm{DA}$, incubated at $37^{\circ} \mathrm{C}$ for $30 \mathrm{~min}$ in the darkness. Furthermore, cells were harvested and the generation of ROS was quantified by measuring the intracellular fluorescence intensity by a flow cytometer. The samples were then analyzed with FlowJo 7.6.1.

2.6. Measurement of Mitochondrial Membrane Potential $(\Delta \psi m)$ and the Activities of Antioxidant Enzymes. The mitochondrial membrane potential was tested using Rhodamine123 (Rh123) as previously described [20]. As well, TSOD, CAT, and GSH-Px activities were all measured as previously described using a colorimetric assay kit according to the manufacturers' instructions [20].

2.7. Immunoblotting. Cells were incubated in 6-well plates at a density of $1 \times 10^{6}$ cells/well. After exposure to $\mathrm{H}_{2} \mathrm{O}_{2}$ $(275 \mu \mathrm{M})$ and/or indicated concentrations of $p$-CA for $24 \mathrm{~h}$, the cells were washed twice with ice-cold PBS and then lysed using RIPA buffer for $30 \mathrm{~min}$ on ice. Protein concentrations were quantified using the BCA protein assay kit [21]. And then, protein from each sample $(50 \mu \mathrm{g})$ was separated by $12 \%$ SDS-PAGE gels and transferred onto nitrocellulose membranes. After incubation with primary antibodies against cleaved caspase-3, cleaved caspase-9, p-p-38, pERK, $\mathrm{p}$-JNK, and $\beta$-actin, followed by incubations with the appropriate secondary antibodies conjugated with HRP as our previously described method [22], the blots were detected by enhanced chemiluminescence (ECL), and then protein bands were quantified by densitometric analysis using Image-Pro Plus ${ }^{\circledR}$ software (Media Cybernetics Inc., USA).

2.8. Statistical Analysis. The data are presented as the mean value \pm standard error of the mean (SEM). The difference between the mean values was evaluated using one-way ANOVA, followed by Duncan's multiple range tests. Comparisons were performed using GraphPad Prism 5.0 software (GraphPad Software Inc., San Diego, CA, USA). A $P$ value $<0.05$ was considered statistically significant.

\section{Results and Discussion}

It is well-known that the apoptosis of lens epithelial cells plays a vital role in cataract formation, and oxidative stress induced by ROS such as $\mathrm{O}_{2}{ }^{-}$and $\mathrm{H}_{2} \mathrm{O}_{2}$ has been recognized as an important mediator to induce apoptosis of lens epithelial cells $[3,5,6]$. Therefore, in the study, $\mathrm{H}_{2} \mathrm{O}_{2}$ was used to induce oxidative injury of lens epithelial cells. After $\mathrm{H}_{2} \mathrm{O}_{2}$ exposure, the cells showed a high cell apoptosis rate and $275 \mu \mathrm{M} \mathrm{H} \mathrm{H}_{2} \mathrm{O}_{2}$ was set as the working concentration (Figure 1(b)). In parallel, HLE cells were treated with 


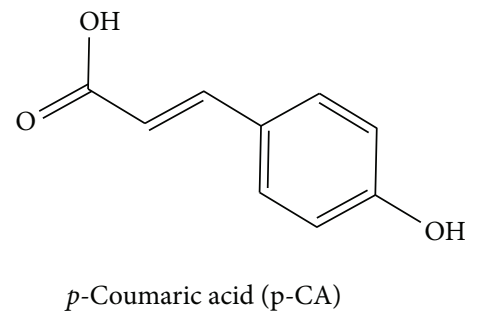

(a)

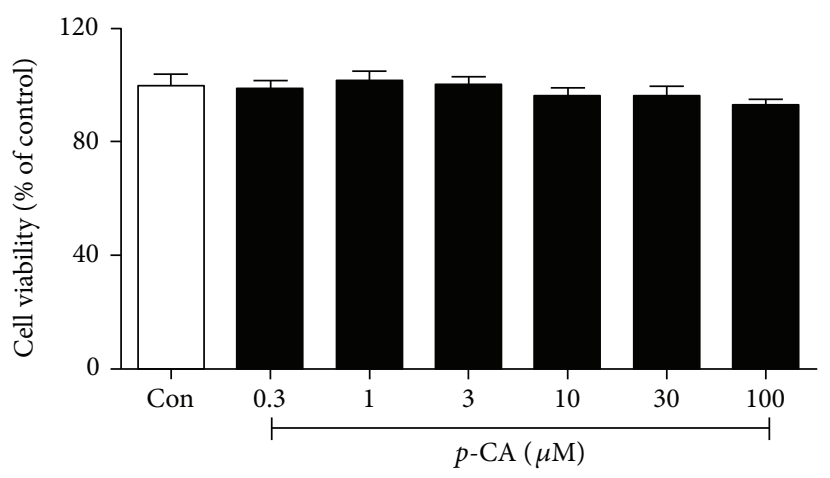

(c)

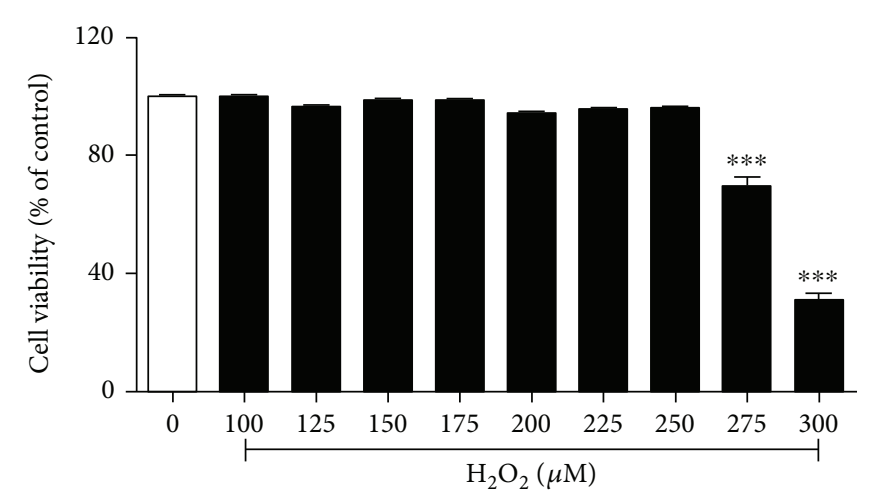

(b)

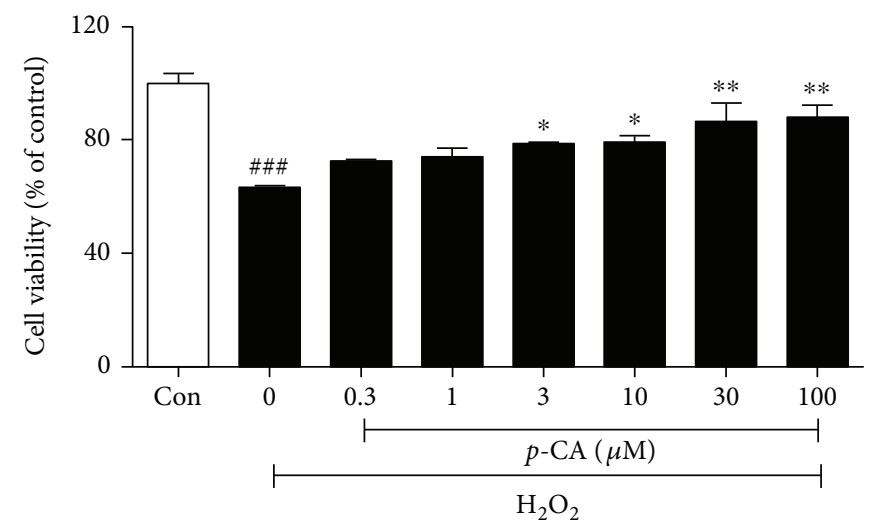

(d)

Figure 1: Effects of $p$-CA on cell viability of $\mathrm{H}_{2} \mathrm{O}_{2}$-induced cell death in HLE cells. (a) Structure of $p$-CA. (b) HLE cells were treated with a series of $\mathrm{H}_{2} \mathrm{O}_{2}$ concentrations $(0-300 \mu \mathrm{M})$ for $24 \mathrm{~h}$. (c) HLE cells were incubated with different concentrations of $p$-CA ( $\left.0-100 \mu \mathrm{M}\right)$ for $24 \mathrm{~h}$. (d) HLE cells are preincubated with $p$-CA $(0-100 \mu \mathrm{M})$ for $2 \mathrm{~h}$ before $275 \mu \mathrm{M} \mathrm{H}_{2} \mathrm{O}_{2}$ treated for $24 \mathrm{~h}$. Cell viability was measured using the MTT method. Data are expressed as the mean $\pm \operatorname{SEM}(n=3)$. \#\#\# $P<0.001$, compared with the untreated control group; ${ }^{*} P<0.05,{ }^{* *} P<0.01$ and ${ }^{* * *} P<0.001$, compared with the $\mathrm{H}_{2} \mathrm{O}_{2}$-treated group.

different concentrations of $p$-CA $(0,0.3,1,3,10,30$, and $100 \mu \mathrm{M})$ for $24 \mathrm{~h}$ and no significant cytotoxicity was observed (Figure 1(c)). And then, the dose response of $p$-CA was assayed on $\mathrm{H}_{2} \mathrm{O}_{2}$-treated HLE cells, and the result showed that pretreatment with $p$-CA $(3-100 \mu \mathrm{M})$ significantly prevented $\mathrm{H}_{2} \mathrm{O}_{2}$-induced cell death in a dose-dependent manner (Figure $1(\mathrm{~d})$ ). To quantitatively examine the protective potential of $p$-CA against $\mathrm{H}_{2} \mathrm{O}_{2}$-induced cell death in HLE cells, the percentage of apoptotic cells was detected by the annexin V/PI double staining method. As shown in Figure 2(a), the percentage of total apoptotic cells (the sum of early-stage apoptotic cells (annexin $\mathrm{V}^{+} / \mathrm{PI}^{-}$cells) and late-stage apoptotic cells (annexin $\mathrm{V}^{+} / \mathrm{PI}^{+}$)) was significantly increased after the exposure of $275 \mu \mathrm{M} \mathrm{H}_{2} \mathrm{O}$. Compared to the cells treated with $\mathrm{H}_{2} \mathrm{O}_{2}$ alone, pretreatment with $p$-CA $(3,10$, and $30 \mu \mathrm{M})$ resulted in a significant decrease of apoptotic cells in the total population of cells in a dosedependent manner. Caspases are the main initiators and executioners of apoptosis [23, 24]. As one of the key effectors, caspase- 3 is activated through cleavage by caspase- 9 and involved in the mitochondria-mediated pathway. We thus examined the expressions of cleaved caspase- 3 and cleaved caspase-9 using Western blot. As shown in Figure 2(b), the expressions of cleaved caspase- 3 and cleaved caspase- 9 were markedly upregulated after $\mathrm{H}_{2} \mathrm{O}_{2}$ treatment. In contrast, pretreatment with $p$-CA $(3,10$, and $30 \mu \mathrm{M})$ significantly inhibited the upregulation of cleaved caspase- 3 and cleaved caspase-9. Collectively, these results suggested that $p$-CA exhibits a potent protective effect against $\mathrm{H}_{2} \mathrm{O}_{2}$-induced apoptosis in HLE cells.

Oxidative stress can be defined as the imbalance between prooxidant/antioxidant that can occur as a result of an increase in free radical production and/or a decrease in radical scavenging capability of antioxidant defense systems. We therefore detected the production of intracellular free radical ROS in $\mathrm{H}_{2} \mathrm{O}_{2}$-induced HLE cells, as shown in Figure 3(a). When the cells were exposed to $\mathrm{H}_{2} \mathrm{O}_{2}$, the generation of ROS increased significantly, whereas pretreatment with $p$ CA $(3,10$, and $30 \mu \mathrm{M})$ significantly inhibited $\mathrm{H}_{2} \mathrm{O}_{2}$-induced production of intracellular ROS in a dose-dependent manner. The mitochondria are the major location to produce intracellular ROS, and ROS overload would result in lysosomal leakage through the mitochondrial outer membrane and mitochondrial dysfunction. A significant reduction of mitochondrial membrane potential $(\Delta \psi \mathrm{m})$ is a symbolic feature of early apoptosis. We further determined the loss of $\Delta \psi \mathrm{m}$ in $\mathrm{H}_{2} \mathrm{O}_{2}$-induced HLE cells. As shown in Figure 3(b), exposure of HLE cells to $\mathrm{H}_{2} \mathrm{O}_{2}$ for $6 \mathrm{~h}$ could significantly 

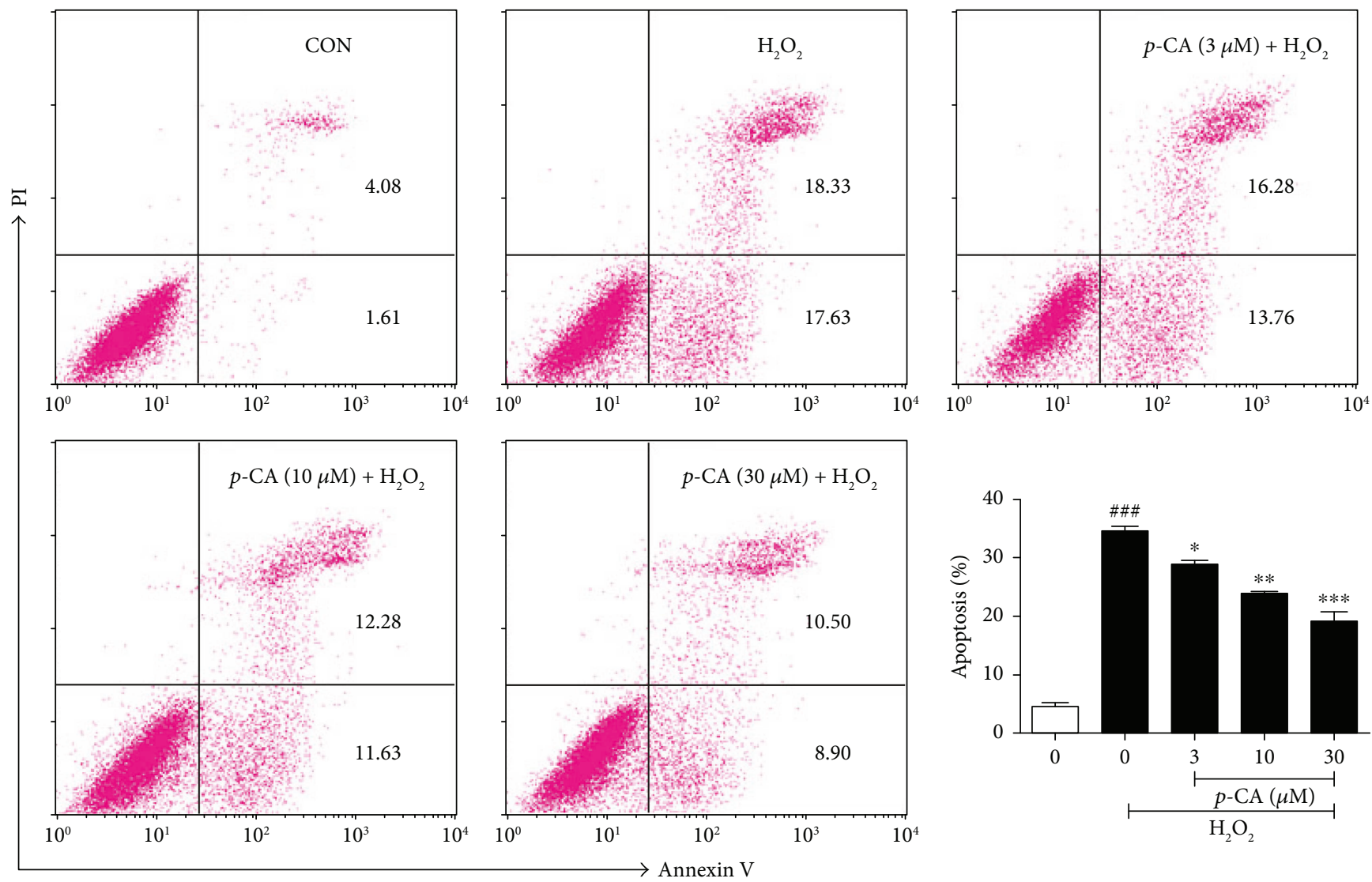

(a)
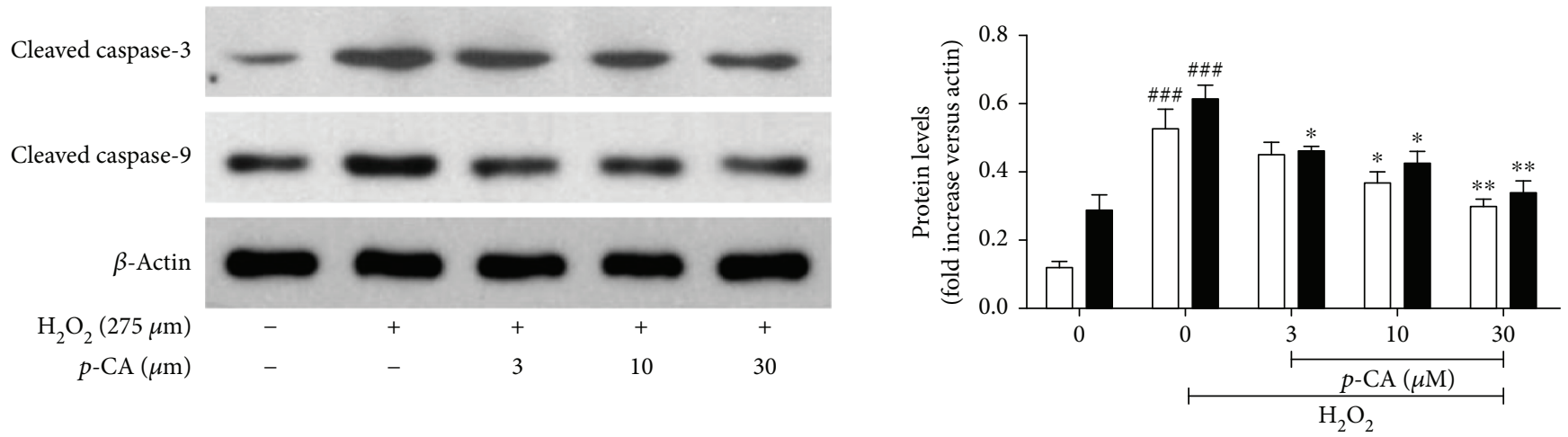

Cleaved caspase- 3

Cleaved caspase-9

(b)

FIGURE 2: $p$-CA prevented $\mathrm{H}_{2} \mathrm{O}_{2}$-induced cell apoptosis in HLE cells. (a) HLE cells were pretreated with $p$-CA $(3,10$, and $30 \mu \mathrm{M})$ for $2 \mathrm{~h}$ before $275 \mu \mathrm{M} \mathrm{H}_{2} \mathrm{O}_{2}$ treatment for $6 \mathrm{~h}$. The apoptotic cells were detected by flow cytometry after staining with both FITC annexin V and PI. (b) HLE cells were pretreated with $p$-CA $(3,10$, and $30 \mu \mathrm{M})$ for $2 \mathrm{~h}$ before $275 \mu \mathrm{M} \mathrm{H}_{2} \mathrm{O}_{2}$ treatment for $24 \mathrm{~h}$. Cleaved caspase-3 and cleaved caspase- 9 expressions were measured by Western blot. Data are expressed as the mean \pm SEM $(n=3)$. \#\#\#P<0.001, compared with the untreated control group; ${ }^{*} P<0.05,{ }^{* *} P<0.01$, and ${ }^{* * *} P<0.001$, compared with the $\mathrm{H}_{2} \mathrm{O}_{2}$-treated group.

increase the percentage of cells with $\Delta \psi \mathrm{m}$ loss, which is up to $29.0 \%$, and pretreatment with $p$-CA $(3,10$, and $30 \mu \mathrm{M})$ could significantly reduce the percentage of cells with $\Delta \psi \mathrm{m}$ loss to $23.7 \%, 21.2 \%$, and $15.8 \%$ in a dose-dependent manner. In parallel, we also detected the radical scavenging capability of antioxidant defense systems of HLE cells, such as the activities of T-SOD, GSH-Px, and CAT enzymes. Compared to the untreated control, $\mathrm{H}_{2} \mathrm{O}_{2}$ decreased the activities of $\mathrm{T}$ SOD, CAT, and GSH-Px near 2-fold. In $\mathrm{H}_{2} \mathrm{O}_{2}$-treated HLE cells, pretreatment with $p$-CA $(3,10$, and $30 \mu \mathrm{M})$ could significantly enhance the activities of T-SOD, CAT, and GSHPx in dose-dependent manners as shown in Figure 4. These results indicated that $p$-CA possesses potent antioxidant activities against $\mathrm{H}_{2} \mathrm{O}_{2}$-induced impairment in HLE cells. 

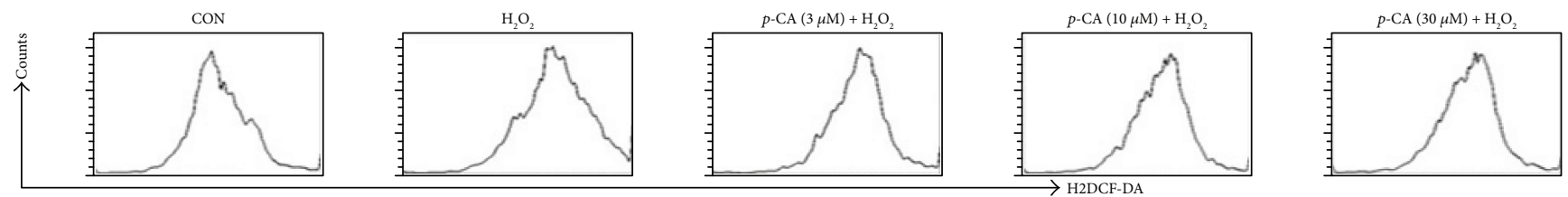

(a)
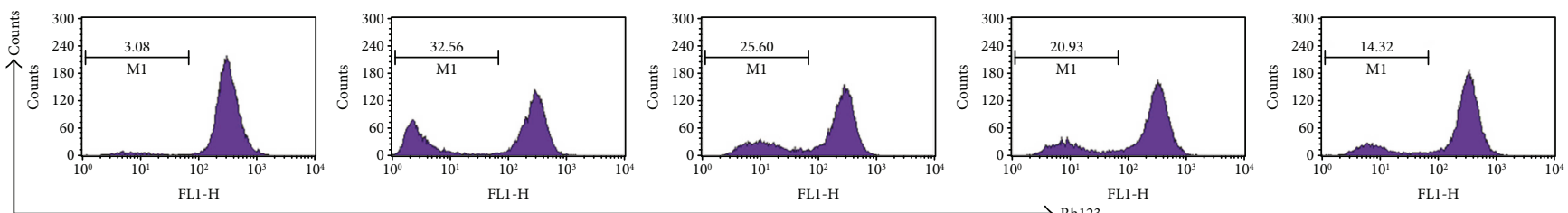

(b)

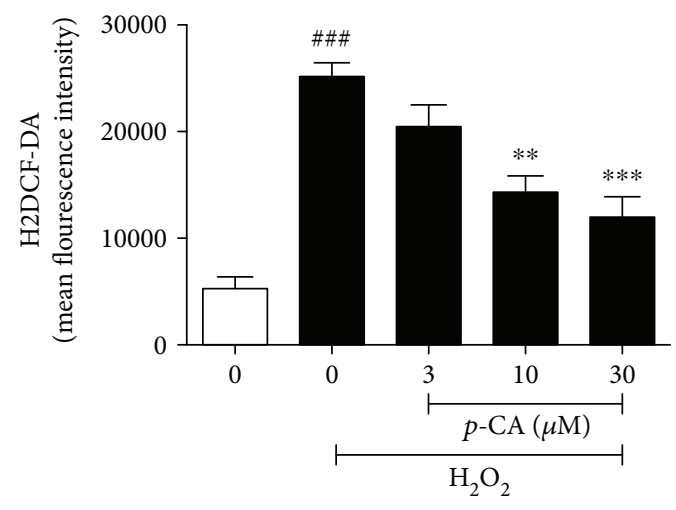

(c)

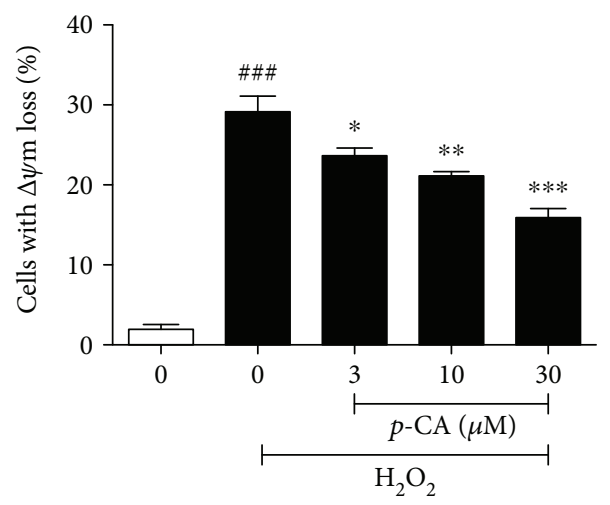

(d)

FIGURE 3: $p$-CA suppressed intracellular ROS production and mitochondrial membrane potential loss in $\mathrm{H}_{2} \mathrm{O}_{2}$-treated HLE cells. (a) HLE cells were pretreated with $p$-CA $(3,10$, and $30 \mu \mathrm{M})$ for $2 \mathrm{~h}$ before $275 \mu \mathrm{M} \mathrm{H}_{2} \mathrm{O}_{2}$ treatment for $6 \mathrm{~h}$. After staining with H2DCF-DA, cells were incubated at $37^{\circ} \mathrm{C}$ for $30 \mathrm{~min}$ in the darkness and then detected by flow cytometry. (b) HLE cells were preincubated with $p$-CA (3, 10 , and $30 \mu \mathrm{M}$ ) for $2 \mathrm{~h}$ before $275 \mu \mathrm{M} \mathrm{H}_{2} \mathrm{O}_{2}$ treatment for $6 \mathrm{~h}$. Cells were incubated with $\mathrm{Rh} 123$ for $30 \mathrm{~min}$ at $37^{\circ} \mathrm{C}$, and then the fluorescent intensity was analyzed using flow cytometry. Data are expressed as the mean \pm SEM $(n=3)$. \#\#\# $P<0.001$, compared with the untreated control group; ${ }^{*} P<0.05,{ }^{* *} P<0.01$, and ${ }^{* * *} P<0.001$, compared with the $\mathrm{H}_{2} \mathrm{O}_{2}$-treated group.

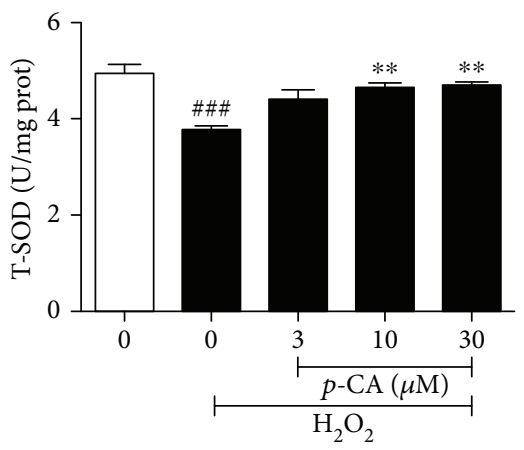

(a)

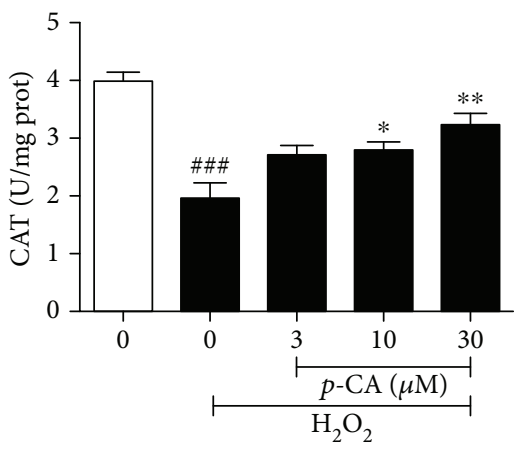

(b)

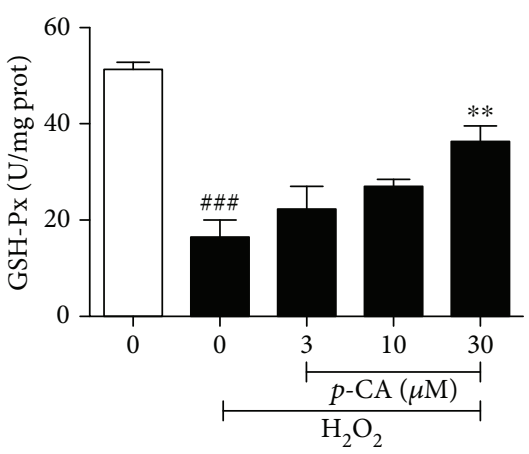

(c)

FIgure 4: $p$-CA enhanced the activities of T-SOD, CAT, and GSH-Px in $\mathrm{H}_{2} \mathrm{O}_{2}$-treated HLE cells. HLE cells were pretreated on $p$-CA (3, 10, and $30 \mu \mathrm{M}$ ) for $2 \mathrm{~h}$ before $275 \mu \mathrm{M} \mathrm{H}_{2} \mathrm{O}_{2}$ treatment for $24 \mathrm{~h}$. The activities of T-SOD (a), CAT (b), and GSH-Px (c) were measured by commercial assay kits. Data were expressed as the mean $\pm \operatorname{SEM}(n=3)$. ${ }^{\# \#} P<0.001$, compared with the untreated control group; ${ }^{*} P<0.05$ and ${ }^{* *} p<0.01$, compared with the $\mathrm{H}_{2} \mathrm{O}_{2}$-treated group.

To explore the molecular mechanisms involved in the protective effects of $p$-CA against $\mathrm{H}_{2} \mathrm{O}_{2}$-induced apoptosis, we evaluated the possible influence of this compound on the expression of mitogen-activated protein kinases (MAPKs), namely, ERK, JNK, and p38, which play important roles in the regulation of intracellular metabolism and responding 

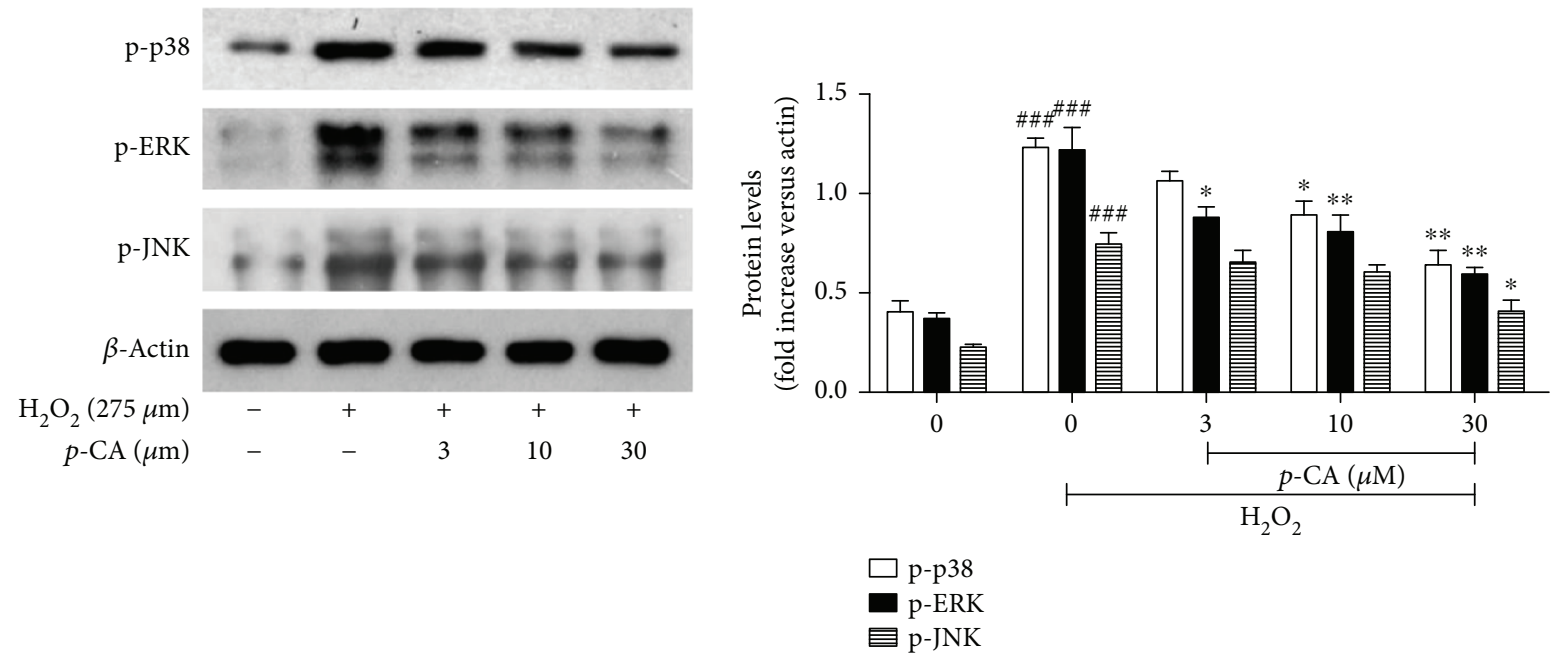

(a)

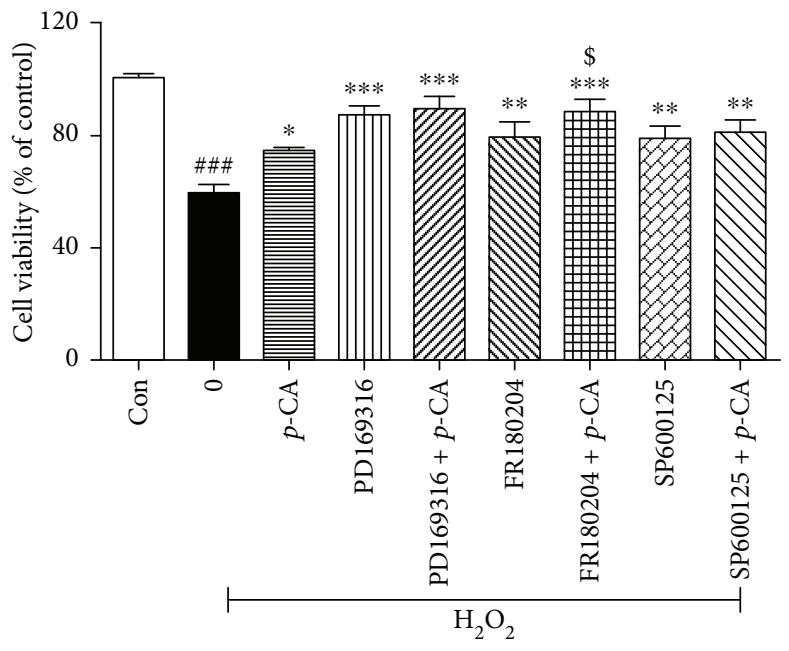

(b)

Figure 5: $p$-CA suppressed MAPK signals in $\mathrm{H}_{2} \mathrm{O}_{2}$-treated HLE cells. (a) HLE cells were pretreated on $p$-CA ( 3 , 10, and $\left.30 \mu \mathrm{M}\right)$ for $2 \mathrm{~h}$ before $275 \mu \mathrm{M} \mathrm{H}_{2} \mathrm{O}_{2}$ treatment for $24 \mathrm{~h}$. Cells were lysed, and then p-p-38, p-ERK, and p-JNK expressions were measured using Western blot. (b) HLE cells were pretreated on $p$-CA $(10 \mu \mathrm{M})$ or ERK inhibitor (FR180204, 1.25 $\mu \mathrm{M}$ ) or p-38 inhibitor (PD169316, $1.25 \mu \mathrm{M})$ or JNK inhibitor

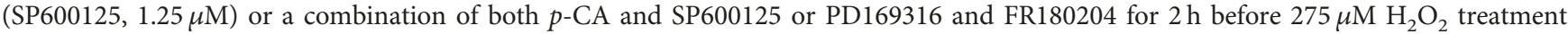
for $24 \mathrm{~h}$; then the cell viability was measured using the MTT method. Data are expressed as the mean $\pm \mathrm{SEM}(n=3)$. \#\#\# $P<0.001$, compared with the untreated control group; ${ }^{*} P<0.05$, ${ }^{* *} P<0.01$ and ${ }^{* * *} P<0.001$, compared with the $\mathrm{H}_{2} \mathrm{O}_{2}$-treated group; and ${ }^{\$} P<0.05$, compared with the $\mathrm{H}_{2} \mathrm{O}_{2}+p$-CA group using Student's $t$-test.

to external stress [6]. Several previous investigations reported that $p$-CA reduced the oxidative stress of various cells via the inhibition of the MAPK signaling cascade [25-27]. Our data showed that (Figure 5(a)) incubation with $\mathrm{H}_{2} \mathrm{O}_{2}$ led to a massive increase of p-p38, p-ERK, and p-JNK. As expected, increased p-p38, p-JNK, and p-ERK were significantly rescued by $p$-CA in a dose-dependent manner. To further confirm the role of the MAPK signaling pathway to mediate the inhibitory effect of $p$-CA on $\mathrm{H}_{2} \mathrm{O}_{2}$-induced apoptosis in HLE cells, we have detected the cell viability of cells exposed to $\mathrm{H}_{2} \mathrm{O}_{2}$ with the ERK inhibitor (U0126) or p-38 inhibitor (LY2228820) or JNK inhibitor (SP600125), respectively. As shown in Figure 5(b), compared to cells treated with $p$-CA alone in the presence of $\mathrm{H}_{2} \mathrm{O}_{2}$, HLE cells treated with $p$-CA combined with LY2228820 or U0126 or SP600125 in the exposure of $\mathrm{H}_{2} \mathrm{O}_{2}$ exhibited a much higher cell viability, which displayed the protective effect of $p$-CA on $\mathrm{H}_{2} \mathrm{O}_{2}$ induced apoptosis in HLE cells via affecting MAPK signaling pathways.

\section{Conclusion}

In conclusion, the data from this study demonstrate that p-CA, a natural compound, could protect HLE cells from oxidative stress-induced apoptosis through modulating MAPK signaling pathways. Our findings suggest a potential use of $p$-CA in the prevention of cataractogenesis. 


\section{Conflicts of Interest}

The authors declare that they have no conflicts of interest.

\section{Acknowledgments}

This research was supported by the National Natural Science Foundation of China (nos. 81660479 and 21102025) and Natural Research Platform (no. 2016-004) of the Department of Education, Guizhou Province, China, and the launching fund of Scientific Research for New Teachers of Shenzhen University (no. 2018020).

\section{References}

[1] M. Cai, J. Li, S. Lin et al., "Mitochondria-targeted antioxidant peptide SS31 protects cultured human lens epithelial cells against oxidative stress," Current Eye Research, vol. 40, no. 8, pp. 822-829, 2015.

[2] L. C. Meekins and N. A. Afshari, "Ever-evolving technological advances in cataract surgery: can perfection be achieved?" Current Opinion in Ophthalmology, vol. 23, no. 1, pp. 1-2, 2012.

[3] A. Spector and W. H. Garner, "Hydrogen peroxide and human cataract," Experimental Eye Research, vol. 33, no. 6, pp. 673681, 1981.

[4] L. Li, J. S. Duker, Y. Yoshida et al., "Oxidative stress and antioxidant status in older adults with early cataract," Eye, vol. 23, no. 6, pp. 1464-1468, 2009.

[5] R. J. W. Truscott, "Age-related nuclear cataract-oxidation is the key," Experimental Eye Research, vol. 80, no. 5, pp. 709725, 2005.

[6] K. Yao, L. Zhang, P. P. Ye, X. J. Tang, and Y. D. Zhang, "Protective effect of magnolol against hydrogen peroxide-induced oxidative stress in human lens epithelial cells," The American Journal of Chinese Medicine, vol. 37, no. 4, pp. 785-796, 2009.

[7] X. Tang, K. Yao, L. Zhang, Y. Yang, and H. Yao, "Honokiol inhibits $\mathrm{H}_{2} \mathrm{O}_{2}$-induced apoptosis in human lens epithelial cells via inhibition of the mitogen-activated protein kinase and Akt pathways," European Journal of Pharmacology, vol. 650, no. 1, pp. 72-78, 2011.

[8] S. M. An, J.-S. Koh, and Y. C. Boo, "p-Coumaric acid not only inhibits human tyrosinase activity in vitro but also melanogenesis in cells exposed to UVB," Phytotherapy Research, vol. 24, pp. n/a-1180, 2010.

[9] L. R. Ferguson, I. F. Lim, A. E. Pearson, J. Ralph, and P. J. Harris, "Bacterial antimutagenesis by hydroxycinnamic acids from plant cell walls," Mutation Research/Genetic Toxicology and Environmental Mutagenesis, vol. 542, no. 1-2, pp. 49-58, 2003.

[10] C. Luceri, L. Giannini, M. Lodovici et al., " $p$-Coumaric acid, a common dietary phenol, inhibits platelet activity in vitro and in vivo," British Journal of Nutrition, vol. 97, no. 3, pp. 458463, 2007.

[11] D. Navaneethan and M. Rasool, " $p$-Coumaric acid, a common dietary polyphenol, protects cadmium chloride-induced nephrotoxicity in rats," Renal Failure, vol. 36, no. 2, pp. 244-251, 2014.

[12] S. J. Pragasam, V. Venkatesan, and M. Rasool, "Immunomodulatory and anti-inflammatory effect of $p$-coumaric acid, a common dietary polyphenol on experimental inflammation in rats," Inflammation, vol. 36, no. 1, pp. 169-176, 2013.
[13] N. Prasanna, D. N. Krishnan, and M. Rasool, "Sodium arsenite-induced cardiotoxicity in rats: protective role of p-coumaric acid, a common dietary polyphenol," Toxicology Mechanisms and Methods, vol. 23, no. 4, pp. 255-262, 2013.

[14] M. Lodovici, S. Caldini, L. Morbidelli, V. Akpan, M. Ziche, and P. Dolara, "Protective effect of 4-coumaric acid from UVB ray damage in the rabbit eye," Toxicology, vol. 255, no. 1-2, pp. 1-5, 2009.

[15] M. Lodovici, L. Raimondi, F. Guglielmi, S. Gemignani, and P. Dolara, "Protection against ultraviolet B-induced oxidative DNA damage in rabbit corneal-derived cells (SIRC) by 4coumaric acid," Toxicology, vol. 184, no. 2-3, pp. 141-147, 2003.

[16] M. Larrosa, M. Lodovici, L. Morbidelli, and P. Dolara, "Hydrocaffeic and $p$-coumaric acids, natural phenolic compounds, inhibit UV-B damage in WKD human conjunctival cells in vitro and rabbit eye in vivo," Free Radical Research, vol. 42, no. 10, pp. 903-910, 2008.

[17] P. Stanely Mainzen Prince and A. J. Roy, “p-Coumaric acid attenuates apoptosis in isoproterenol-induced myocardial infarcted rats by inhibiting oxidative stress," International Journal of Cardiology, vol. 168, no. 4, pp. 3259-3266, 2013.

[18] S. Y. Hong, W. S. Jeong, and M. Jun, "Protective effects of the key compounds isolated from Corni fructus against $\beta$-amyloid-induced neurotoxicity in PC12 cells," Molecules, vol. 17, no. 9, pp. 10831-10845, 2012.

[19] H. T. Xiao, X. L. Qi, Y. Liang et al., "Membrane permeabilityguided identification of neuroprotective components from Polygonum cuspidatun," Pharmaceutical Biology, vol. 52, no. 3, pp. 356-361, 2014.

[20] B. Liang, W. Wei, J. Wang et al., "Protective effects of Semiaquilegia adoxoides $n$-butanol extract against hydrogen peroxideinduced oxidative stress in human lens epithelial cells," Pharmaceutical Biology, vol. 54, no. 9, pp. 1656-1663, 2016.

[21] M. M. Bradford, "A rapid and sensitive method for the quantitation of microgram quantities of protein utilizing the principle of protein-dye binding," Analytical Biochemistry, vol. 72, no. 1-2, pp. 248-254, 1976.

[22] H. T. Xiao, C. Y. Lin, D. H. H. Ho et al., "Inhibitory effect of the gallotannin corilagin on dextran sulfate sodium-induced murine ulcerative colitis," Journal of Natural Products, vol. 76, no. 11, pp. 2120-2125, 2013.

[23] V. Bantseev and H.-Y. Youn, "Mitochondrial "movement" and lens optics following oxidative stress from UV-B irradiation," Annals of the New York Academy of Sciences, vol. 1091, no. 1, pp. 17-33, 2006.

[24] B. B. Wolf and D. R. Green, "Suicidal tendencies: apoptotic cell death by caspase family proteinases," The Journal of Biological Chemistry, vol. 274, no. 29, pp. 20049-20052, 1999.

[25] H.-S. Lee, Y. D. Kim, B. R. Na et al., "Phytocomponent $p$-hydroxycinnamic acid inhibits T-cell activation by modulation of protein kinase C- $\theta$-dependent pathway," International Immunopharmacology, vol. 12, no. 1, pp. 131-138, 2012.

[26] N. Prasanna and M. Rasool, "Modulation of gene-expression profiles associated with sodium arsenite-induced cardiotoxicity by p-coumaric acid, a common dietary polyphenol," Journal of Biochemical and Molecular Toxicology, vol. 28, no. 4, pp. 174-180, 2014.

[27] C.-S. Kong, C.-H. Jeong, J.-S. Choi, K.-J. Kim, and J.-W. Jeong, "Antiangiogenic effects of $P$-coumaric acid in human endothelial cells," Phytotherapy Research, vol. 27, no. 3, pp. 317-323, 2013. 


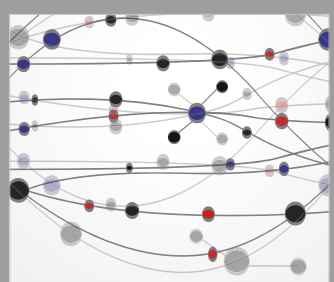

The Scientific World Journal
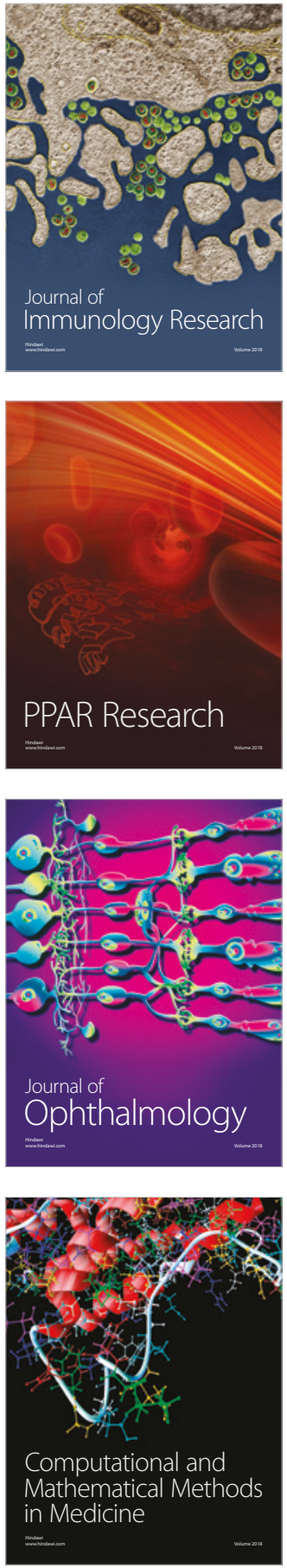

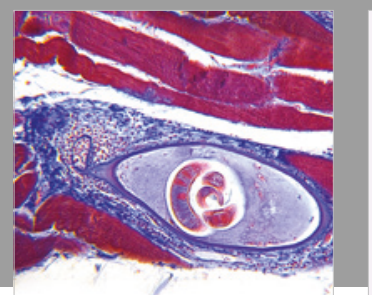

Gastroenterology Research and Practice

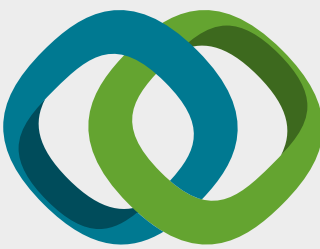

\section{Hindawi}

Submit your manuscripts at

www.hindawi.com
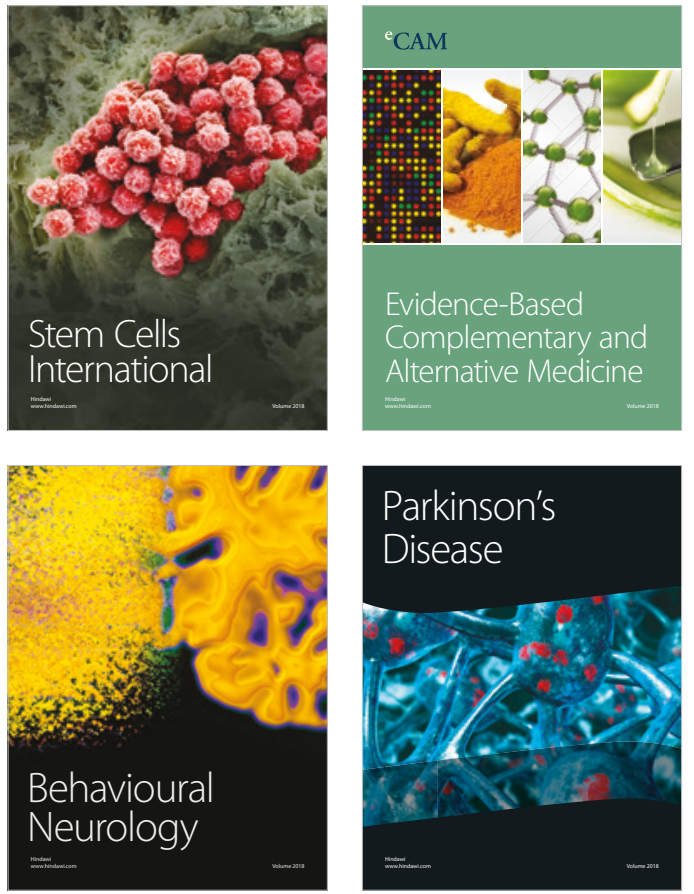

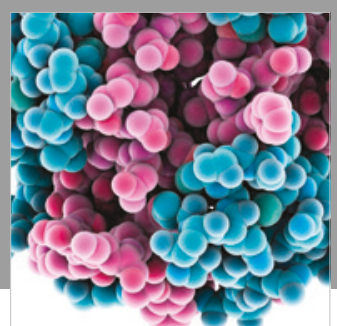

ournal of

Diabetes Research

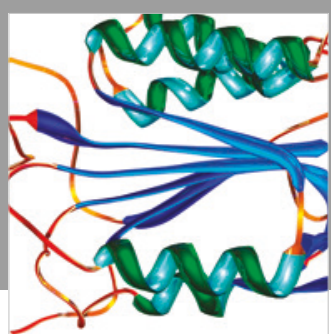

Disease Markers
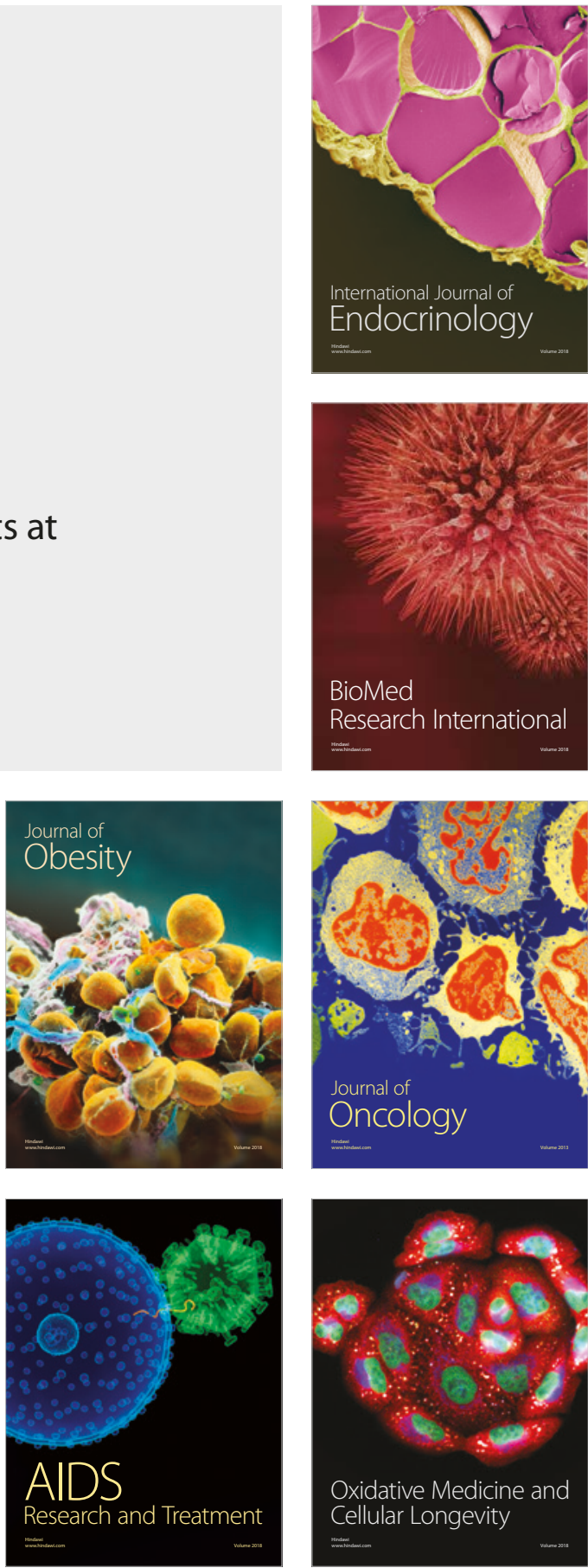